\title{
POTENCIALI EKOLOŠKE PRIDELAVE ZA TRAJNO- STNO LOKALNO OSKRBO S HRANO V SLOVENIJI
}

\author{
Anamarija Slabe*, dr. Barbara Lampič ${ }^{* *}$, dr. Luka Juvančič*** \\ * univ. dipl. ing. kmet., Inštitut za trajnostni razvoj, Metelkova 6, SI-1000 Ljubljana \\ ** Oddelek za geografijo, Filozofska fakulteta Univerze v Ljubljani \\ Aškerčeva 2, SI-1000 Ljubljana \\ *** Oddelek za zootehniko, Biotehniška fakulteta Univerze v Ljubljani \\ Groblje 3, SI-1230 Domžale \\ e-mail: anamarija.slabe@itr.si; barbara.lampic@ff.uni-lj.si; luka.juvancic@bf.uni-lj.si \\ Izvirni znanstveni članek \\ COBISS 1.01
}

\section{Izvleček}

$\mathrm{V}$ prispevku je predstavljena ocena potencialov ekološke pridelave za trajnostno lokalno oskrbo s hrano. S pomočjo rezultatov obsežne terenske raziskave med ekološkimi kmeti smo analizirali obstoječo domačo ekološko pridelavo za trg po vrstah pridelkov in tržnih poteh. Definirali smo glavne prednosti in pomanjkljivosti, ki odločilno vplivajo na razvoj slovenskega trga ekoživil ter posebej izpostavili prostorske razlike. Na osnovi raziskave ocenjujemo, da je v ekološki pridelavi velik neizkoriščen potencial za trajnostno lokalno oskrbo s hrano v Sloveniji.

Ključne besede: ekološka pridelava, pridelovalni potencial, trženje ekoloških pridelkov, trajnostna oskrba s hrano, Slovenija

\section{ORGANIC PRODUCTION POTENTIALS FOR SUSTAINABLE LOCAL FOOD SUPPLY IN SLOVENIA}

\begin{abstract}
The paper is presenting the assessment of organic production potentials for sustainable local food supply. Using the results of extensive field research among organic farmers, we analyzed the existing organic production for the market by the type of products and marketing channels. We defined the main strengths and weaknesses critical to the development of the Slovenian market for organic food, and highlighted spatial differences. We estimate that, especially in the organic production, there is a large untapped potential for sustainable local food supply in Slovenia.
\end{abstract}

Key words: organic production, production potential, marketing of organic products, sustainable food supply, Slovenia 


\section{UVOD}

Vse nižja stopnja samooskrbe s hrano v Sloveniji, ki je po podatkih SURS (2011) v letu 2010 npr. za zelenjavo znašala le $31 \%$, za žito 55 \% in za krompir 64 \%, je sprožila številna vprašanja o potrebnih aktivnostih, ki bi obrnile trend upadajočega pokrivanja lastnih prehranskih potreb. Odzivi na skrb vzbujajoče razmere so prišli v razmeroma kratkem času. Odgovorne politike, pa tudi javnost, so potrebo po spodbujanju večje oskrbe s kakovostnimi slovenskimi živili prepoznale kot ključno za prihodnost kmetijstva in ustrezno preskrbo slovenskega prebivalstva. V Resoluciji o strateških usmeritvah slovenskega kmetijstva in živilstva (2011) sta prehranska varnost in proizvodnja hrane izpostavljeni kot strateški politični vprašanji. »Slovenija mora krepiti svojo proizvodnjo in si prizadevati za ekonomsko učinkovito pokrivanje dela svojih potreb po hrani in tam, kjer smo in bomo konkurenčni, tudi prispevati h globalni prehranski varnosti.« (Resolucija..., 2011).

Pomemben vidik oskrbe slovenskega prebivalstva s hrano je varna in kakovostna hrana. Ekološko kmetijstvo se je kot standardizirana in nadzorovana oblika pridelave na mednarodni ravni začelo uveljavljati v 70. letih 20. st., v Evropski uniji (v nadaljevanju EU) pa so zasebne certifikacijske sheme dopolnili še z uredbo o ekološki pridelavi leta 1991. Obseg nadzorovane ekološke pridelave tako v državah EU kot drugje po svetu iz leta v leto narašča. V obdobju od leta 2000 do 2008 je bila v državah EU-15 povprečna letna rast ekološke pridelave kar $6,7 \%$, v novih pridruženih članicah EU pa celo $20 \%$ (An analysis of the EU organic sector, 2010). K temu po eni strani prispeva naraščajoče povpraševanje po ekoloških živilih, po drugi pa se ekološko kmetijstvo zaradi visoke stopnje zagotavljanja javnih dobrin (npr. pozitivni vplivi na kakovost voda in tal ter na biotsko raznovrstnost) dodatno spodbuja tudi z določenimi ukrepi v okviru Skupne kmetijske politike. V Sloveniji je bilo leta 2010 v ekološko pridelavo vključenih 2218 kmetij s 30.696 ha kmetijskih zemljišč v uporabi (v nadaljevanju KZU), kar je 6,5 \% vseh KZU (MKGP, 2011). Podatki kažejo, da se rast števila ekoloških kmetij in obsega ekološko obdelanih kmetijskih zemljišč v primerjavi z nekaj zadnjimi leti po letu 2008 upočasnjuje.

Drugače je s povpraševanjem, oziroma dejansko potrošnjo ekoživil v Sloveniji. Najnovejša raziskava za Slovenijo kaže, da je delež ekoloških živil v skupni potrošnji vseh živil v Sloveniji nekaj nad 1 \% (Slabe in sod., 2010). Primerljivi rezultati nekaterih drugih evropskih držav so bistveno višji. V Avstriji je na primer delež ekoloških živil $6 \%$, na Danskem celo 7,2 \% skupne potrošnje živil (The organic market in Europe, 2011). Ob tem kaže poudariti, da obseg potrošnje ekoživil v Sloveniji hitro narašča, po nekaterih ocenah (Slabe in sod., 2010) na letni ravni 10 do 15 \%. Poročila o gibanjih na trgu ekoživil kažejo, da so se pozitivni trendi kljub gospodarski krizi večinoma ohranili, torej lahko pričakujemo nadaljnjo rast tudi v prihodnosti (Marktbericht, 2011).

Na trgu ekoživil je zelo značilna tudi izrazita naklonjenost potrošnikov lokalno pridelanim živilom. To je povezano predvsem z željo po višji kakovosti, zlasti v primeru sveže zelenjave, sadja in mleka, torej pri tistih živilih, kjer je čas od spravila pridelka do 
nakupa razmeroma kratek. Hkrati je vse pomembnejši dejavnik tudi okoljska osveščenost kupcev. Kot kažejo rezultati intervjujev s trgovci (Slabe in sod., 2010), pa tudi raziskave med potrošniki (Terenska raziskava - anketiranje potrošnikov, 2010), tudi slovenski potrošniki ekoživil dajejo prednost lokalnim, oziroma slovenskim ekoživilom.

Prve doslej pridobljene ocene obsega ekoživil slovenskega izvora v domači potrošnji kažejo, da je bil v letu 2009 njihov delež v skupni vrednosti vseh prodanih ekoživil komaj 20-odstoten (Slabe in sod., 2010). Istočasno uvoz ekoživil iz leta v leto raste (Slabe in sod., 2010), na podlagi česar lahko sklepamo, da domači pridelovalci in predelovalci ne zmorejo zadovoljiti povpraševanja potrošnikov.

Za trženje slovenskih ekoživil so značilne tudi specifične tržne poti, oziroma velik delež neposrednega trženja. Poleg že uveljavljenih neposrednih tržnih poti, kot so ekološke tržnice in neposredna prodaja na kmetiji, so se razvile tudi specifične oblike, na primer 'ekozabojčki' in partnersko kmetovanje. Tudi interes posameznih kmetov za prodajo institucionalnim kupcem, kakršni so šole, vrtci ipd., se povečuje (Slabe in sod., 2010), večji vstop ekološko pridelane hrane v javne ustanove pa pričakujemo po sprejemu Uredbe o zelenem javnem naročanju (Uredba o zelenem javnem naročanju (predlog), 2010; Akcijski načrt za zeleno javno naročanje za obdobje 2009-2012, 2009).

Naštete značilnosti kažejo, da nudi ekološka pridelava ugodno izhodišče za lokalno trajnostno oskrbo prebivalstva s hrano, saj:

- je ekološka pridelava najbolj trajnostna oblika pridelave hrane, predvsem z vidika ohranjanja oziroma izboljševanja okolja, istočasno zagotavlja visoko stopnjo javnih dobrin tudi v lokalnem okolju;

- slovenski potrošniki, še zlasti potrošniki ekoživil, dajejo izrazito prednost lokalno, regionalno ali nacionalno pridelanim in predelanim živilom;

- obstoječa ponudba slovenskih ekoživil ne pokriva trenutnih zahtev/potreb potrošnikov po ekološko pridelani hrani.

V prispevku tako želimo:

- predstaviti ključne rezultate analize domače ekološke pridelave za trg po vrstah pridelkov in tržnih/prodajnih poteh;

- definirati značilnosti tržno naravnanih ekoloških kmetij z vidika demografske vitalnosti, dohodkov iz kmetijske dejavnosti in načrtov za prihodnost;

- predstaviti največje ovire pri povečevanju trženja na slovenskih ekoloških kmetijah, vključno z ovirami pri kmetovanju;

- podati oceno tržnega pridelovalnega potenciala slovenskih ekoloških kmetij in

- nakazati možnosti za izboljšanje lokalne oskrbe s hrano v Sloveniji.

Večina v prispevku predstavljenega gradiva je rezultat projekta CRP Konkurenčnost Slovenije 2006-2013 z naslovom Analiza stanja in potencialov za rast ponudbe ekoloških proizvodov v luči doseganja ciljev Akcijskega načrta za razvoj ekološkega kmetijstva v Sloveniji do leta 2015, ki sta ga izvedla Inštitut za trajnostni razvoj in Oddelek za zootehniko Biotehniške fakultete, terensko delo pa je bilo opravljeno v sodelovanju z Oddelkom za geografijo Filozofske fakultete. 


\section{METODA DELA IN PODATKI}

Stanje slovenske ekološke pridelave za trg, ovire za trženje in načrte ekoloških pridelovalcev glede trženja smo raziskali s pomočjo anketiranja ekoloških kmetij v začetku leta 2010. Vsi prikazani podatki v nadaljevanju so rezultat neposredno s terena pridobljenih podatkov.

Izhodišče raziskave je predpostavka, da dejanski potencial za lokalno oskrbo s hrano predstavljajo tiste ekološke kmetije, ki so že vpete v prodajne poti, ki imajo zadovoljiv obseg kmetijskih obdelovalnih zemljišč, imajo ustrezno socio-demografsko strukturo in hkrati tudi same izkazujejo interes za nadaljnjo pridelavo ekoloških pridelkov.

Okvir vzorčenja ekoloških kmetij, vključenih v raziskavo, je predstavljala zbirka podatkov vseh kmetij, vključenih v nadzor ekološke pridelave v letu 2008 (MKGP, 2008). Podatkovna zbirka je vsebovala podatke o lokaciji kmetij in osnovne strukturne podatke o rastlinski (struktura posevkov oziroma nasadov po posameznih kulturah) in živalski proizvodnji (stalež živine po posameznih kategorijah).

Pri oblikovanju vzorca smo najprej opredelili najnižja merila za uvrstitev v vzorec. Izpolnile so jih kmetije z najmanj 0,5 ha zemlje in so imele v letu 2008 status ekološke kmetije (tj. zaključeno obdobje preusmerjanja). Na ta način smo izločili vse kmetije, ki še ne morejo imeti dovolj izkušenj s trženjem ekoživil, oziroma jih zaradi zelo majhnega obsega pridelave ne uvrščamo med tržne pridelovalce. Merila je izpolnilo 1768 kmetij, tj. 86 \% vseh kmetij, vključenih v register ekoloških pridelovalcev.

Sledilo je oblikovanje reprezentativnega vzorca potencialno tržnih ekoloških kmetij za anketiranje na terenu. V ta namen smo izvedli dvostopenjsko stratifikacijo. Prva raven stratifikacije se je nanašala na velikostni razred kmetije, druga pa na proizvodni tip kmetije. Pri stratifikaciji glede na velikost kmetij smo uporabili podatek o skupni površini kmetijskih zemljišč v obdelavi. Na ta način smo kmetije razvrstili v štiri velikostne razrede: (1) do 5 ha, (2) od 5 do 10 ha, (3) od 10 do 20 ha in (4) nad 20 ha. Glede na prevladujočo rabo zemljišč ter glede na vrsto in intenzivnost živinorejske proizvodnje smo določili štiri proizvodne tipe: poljedelstvo (žita, oljnice, ostalo), trajni nasadi, živinoreja in zelenjava.

Opredeljeni vzorec anketiranih kmetij je reprezentativen glede relativne zastopanosti posameznih velikostnih razredov in proizvodnih tipov. $\mathrm{Z}$ vidika lokalne oskrbe $\mathrm{s}$ hrano je pomembna tudi prostorska razporeditev ekoloških kmetij, zato smo upoštevali tudi zastopanost kmetij po statističnih regijah. Anketirani vzorec ekoloških kmetij solidno odraža značilnosti celotne populacije glede velikostne strukture in zastopanosti posameznih proizvodnih tipov (preglednica 1). 
Slika 1: Anketirane ekološke kmetije po proizvodnem tipu in velikosti

Figure 1: Surveyed organic farms by type of production and size

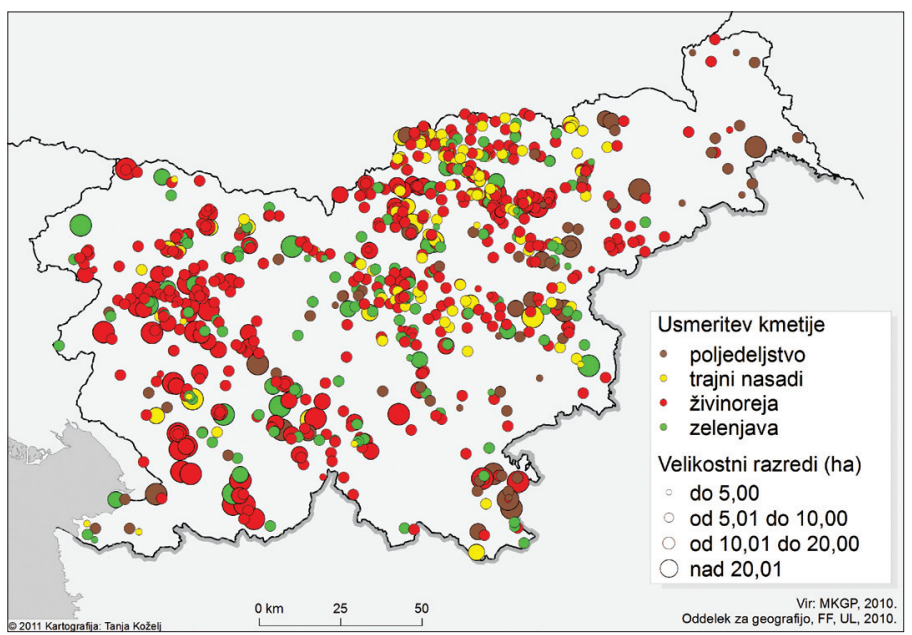

Preglednica 1: Zastopanost posameznih velikostnih razredov in proizvodnih tipov kmetij med ekološkimi kmetijami v Sloveniji in v vzorcu kmetij, vključenih $v$ raziskavo

Table 1: Representation of organic farms by size and types of production in the population and in the sample of surveyed organic farms in Slovenia

\begin{tabular}{|c|c|c|c|c|c|}
\hline & & Slovenija (št.) & Slovenija (\%) & $\begin{array}{c}\text { Anketirani } \\
\text { vzorec kmetij } \\
\text { (št.) } \\
\end{array}$ & $\begin{array}{c}\text { Anketirani } \\
\text { vzorec kmetij } \\
(\%) \\
\end{array}$ \\
\hline \multirow{4}{*}{$\begin{array}{l}\text { Velikostni } \\
\text { razredi kmetij }\end{array}$} & Do 5 ha & 318 & 18,0 & 46 & 18,0 \\
\hline & Od 5 do 10 ha & 629 & 35,6 & 85 & 32,8 \\
\hline & Od 10 do 20 ha & 532 & 30,1 & 82 & 32,0 \\
\hline & 20 ha in več & 288 & 16,3 & 43 & 17,2 \\
\hline \multicolumn{2}{|l|}{ Skupaj } & 1768 & 100,0 & 256 & 100,0 \\
\hline \multirow{4}{*}{$\begin{array}{l}\text { Proizvodni tipi } \\
\text { kmetij }\end{array}$} & Poljedelstvo & 188 & 10,6 & 39 & 15,2 \\
\hline & Trajni nasadi & 271 & 15,3 & 38 & 14,8 \\
\hline & Zelenjava & 263 & 14,9 & 49 & 19,1 \\
\hline & Živinoreja & 1046 & 59,2 & 130 & 50,8 \\
\hline \multicolumn{2}{|l|}{ Skupaj } & 1768 & 100,0 & 256 & 100,0 \\
\hline
\end{tabular}

Vir/Source: MKPG, 2010 
Ker podatkovni zbirki registra ekoloških kmetij vsebujeta podrobne podatke o kmetijski proizvodnji, smo se v vprašalniku osredotočili na ključne socio-ekonomske značilnosti kmetij ter na organiziranost ponudbe in trženja ekoživil na kmetijah.

Anketiranje izbranih kmetij je potekalo v obliki intervjujev na kmetijah od decembra 2009 do marca 2010. Anketiranje so izvajali študentje 4. letnika študija geografije, slušatelji izbirnega predmeta Varstvo geografskega okolja. Anketiranih je bilo 256 kmetij, kar pomeni, da je bila v naše preučevanje vključena vsaka sedma ekološka kmetija v Sloveniji.

Vnos anketnih podatkov in njihova obdelava je bila izvedena v programskem okolju Statistical Package for Social Sciences (SPSS). Obdelava podatkov je vključevala enostavne frekvenčne izračune, izdelavo kontingenčnih tabel ter testiranje statističnih značilnosti razlik med značilnimi skupinami anketiranih kmetij (velikostni razredi, proizvodni tipi, ipd.).

\section{POTENCIALI EKOLOŠKE PRIDELAVEV SLOVENIJI}

V Sloveniji je 1768 ekoloških kmetij z več kot 0,5 ha KZU, njihovo prostorsko razporeditev, proizvodne usmeritve in velikost kaže slika 2. Prikazano je stanje leta 2010, pri čemer kaže opozoriti, da se je število in struktura ekoloških kmetij v zadnjih letih ustalila. Seveda bi bilo zgolj na osnovi statističnih podatkov o številu, proizvodnih tipih in velikosti ekoloških kmetij preveč tvegano sklepati o potencialu za tržno ekološko pridelavo v Sloveniji. Očitna je skromnejša zastopanost ekoloških kmetij na območjih, ki so relativno ugodna za rastlinsko pridelavo (Lampič, 2005; 2008). Prisotnost ekoloških kmetij v severovzhodni in jugovzhodni Sloveniji je najskromnejša, v severovzhodni Sloveniji pa je opazna tudi manjša razvejenost proizvodnih tipov.

Slika 2: Proizvodni tipi in velikost potencialno tržnih ekoloških kmetij v Sloveniji

Figure 2: Types and size of potentially commercial production of organic farms in Slovenia

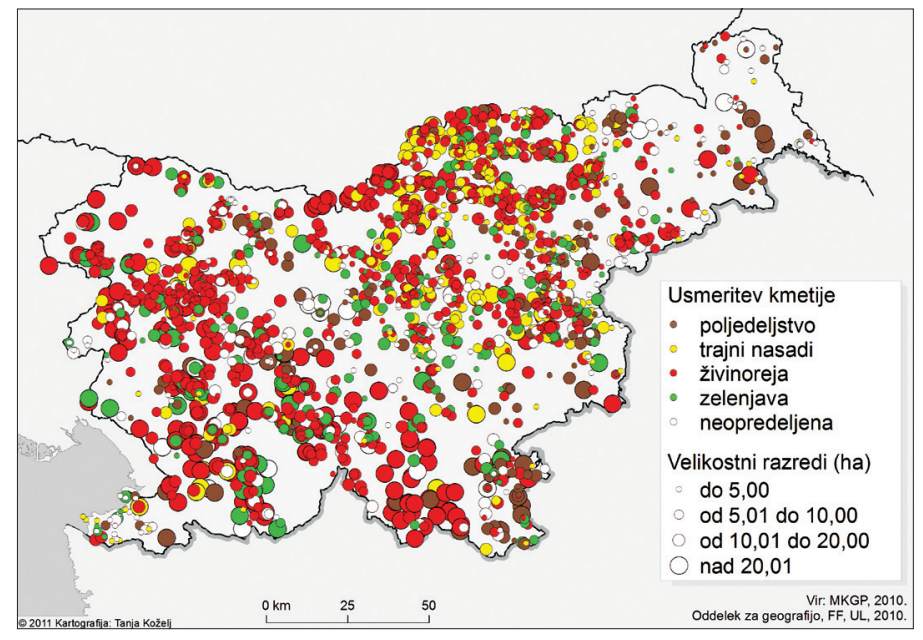

Vir/Source: MKGP, 2010 
Velikostna struktura in pridelovalna usmeritev ekoloških kmetij sta neposredno povezani s pokrajinskimi značilnostmi. Večje in v živinorejo usmerjene ekološke kmetije (ki pa so s pridelovalnega in tržnega vidika pogosto manj učinkovite) očitno prevladujejo v hribovitem zahodnem in kraškem južnem delu, manjše in pridelovalno bolj heterogene pa v osrednjem in vzhodnem delu Slovenije. Živinorejske ekološke kmetije lahko označimo kar kot neizkoriščen tržni potencial, saj svoje proizvode pogosto tržijo kot konvencionalne.

\section{I. Demografski potencial}

$\mathrm{Z}$ vidika potencialov za povečanje trajnostne lokalne oskrbe s hrano lahko kot perspektivne kmetije izpostavljamo tiste, na katerih prebivajo večgeneracijska kmečka gospodinjstva in katerih člani (zlasti mlajša generacija) izkazujejo interes po intenzivnejšem udejstvovanju na kmetiji in po nadaljnji pridelavi ekoloških pridelkov. Dosedanje analize starostno-generacijske strukture gospodinjstev (Klemenčič in sod., 2008; Lampič, 2008; 2011) so se prav na kmečkih gospodinjstvih pokazale kot zelo primerna metoda za ocenjevanje dejanskih in potencialnih razvojnih možnosti same kmetijske dejavnosti in manjših podeželskih območij nasploh. Gre za tipologijo gospodinjstev glede na starostno-generacijsko sestavo članov. Ekološke kmetije v Sloveniji še niso bile raziskane z demografskega vidika, pridobljeni rezultati preučevanja pa izpostavljajo velik pomen človeškega kapitala za bodoči razvoj ekološkega kmetijstva in z njim povezane trajnostne lokalne oskrbe s hrano.

Pri razvrščanju anketiranih kmečkih gospodinjstev glede na njihovo demografsko strukturo smo povzeli pristop, uporabljen v Lampič (2008) in Klemenčič in sod. (2008):

- ostarelo gospodinjstvo: vsi člani so starejši od 70 let;

- $\quad$ starejše gospodinjstvo: vsi člani so starejši od 50 let;

- gospodinjstvo s starejšo srednjo generacijo: sestavljajo ga starši z otroki, starejšimi od 35 let, lahko tudi enočlansko gospodinjstvo, ko je član star od 35 do 50 let;

- gospodinjstvo s srednjo generacijo: otroci so stari od 25 do 35 let, lahko tudi enočlansko gospodinjstvo, ko je član star od 25 do 35 let;

- trigeneracijsko gospodinjstvo: gospodinjstvo sestavljajo člani treh generacij (stari starši, otroci, vnuki). Takšna gospodinjstva so številčnejša in kot taka imajo praviloma na razpolago tudi več razpoložljive delovne sile za delo na kmetiji in z njo povezanimi dejavnostmi;

- gospodinjstvo s srednjo in mlado generacijo: predstavljajo ga starši in otroci, mlajši od 25 let;

- mlada družina: vsi člani so mlajši od 35 let; to so mlade družine, ki se v kmečkih gospodinjstvih redko pojavljajo.

Ustrezne podatke za analizo demografske vitalnosti ekoloških pridelovalcev smo na terenu pridobili za 242 anketiranih kmetij, ki skupaj štejejo 988 članov. V povprečju šteje kmečko gospodinjstvo na ekoloških kmetijah 4,1 člana, številčno najmočnejšo skupino pa predstavljajo trigeneracijska kmečka gospodinjstva, ki jih z vidika razpoložljivosti 
delovne sile lahko označimo kot perspektivna za razvoj kmetije in morebitnih drugih dejavnosti, vezanih na kmetijsko proizvodnjo. Zaradi števila družinskih članov in sestave gospodinjstva je na takšnih kmetijah namreč mogoče celovito in dolgoročno načrtovanje razvoja kmetijskega gospodarstva. $\mathrm{K}$ temu bistveno pripomore razpoložljivost in prilagodljivost lastnega dela, kombinacija izkušenj in znanja, ki jih prenaša starejša generacija, ter podjetnosti, inovativnosti in pripravljenosti na prevzemanje poslovnih tveganj, ki jih običajno pripisujemo mlajši generaciji.

Preglednica 2: Demografska vitalnost ekoloških kmetij v Sloveniji

Table 2: Demographic viability of organic farms in Slovenia

\begin{tabular}{|l|c|c|c|c|}
\hline Demografski tip gospodinjstva* & $\begin{array}{c}\text { Število } \\
\text { gospodinjstev }\end{array}$ & Delež (\%) & $\begin{array}{c}\text { Skupaj število } \\
\text { članov }\end{array}$ & $\begin{array}{c}\text { Povprečna } \\
\text { velikost } \\
\text { gospodinjstva }\end{array}$ \\
\hline Ostarelo gospodinjstvo & 2 & 0,8 & 3 & 1,5 \\
\hline Starejše gospodinjstvo & 28 & 11,6 & 55 & 2,0 \\
\hline $\begin{array}{l}\text { Gospodinjstvo s starejšo srednjo } \\
\text { generacijo }\end{array}$ & 17 & 7,0 & 39 & 2,9 \\
\hline Gospodinjstvo s srednjo generacijo & 30 & 12,4 & 102 & 3,4 \\
\hline Trigeneracijsko gospodinjstvo & 49 & $\mathbf{2 0 , 2}$ & 285 & 5,8 \\
\hline $\begin{array}{l}\text { Gospodinjstvo s srednjo in mlado } \\
\text { generacijo }\end{array}$ & 109 & $\mathbf{4 5 , 0}$ & 477 & 4,4 \\
\hline Mlada družina & 7 & 2,9 & 27 & 3,8 \\
\hline Skupaj & $\mathbf{2 4 2}$ & $\mathbf{1 0 0 , 0}$ & $\mathbf{9 8 8}$ & $\mathbf{4 , 1}$ \\
\hline
\end{tabular}

* Razvrstitev $v$ skupine demografske vitalnosti po Lampič (2008) ter Klemenčič in sod. (2008)

Vir/Source: Anketiranje december 2009 - marec 2010

$\mathrm{Z}$ vidika gospodarske funkcionalnosti in bodočega razvoja lahko sedem navedenih tipov kmečkih gospodinjstev razvrstimo v naslednje skupine:

- perspektivne (mlade družine, kmetije s srednjo in mlado generacijo ter trigeneracijske kmetije);

- pogojno perspektivne (kmetije s srednjo ter kmetije s srednjo in starejšo generacijo) in

- manj perspektivne (t.i. starejše in ostarele kmetije). 
Slika 3: Ocenjen razvojni potencial ekoloških kmetij glede na demografsko sestavo kmečkega gospodinjstva

Figure 3: The estimated development potential of organic farms in relation to the demographic composition of rural households

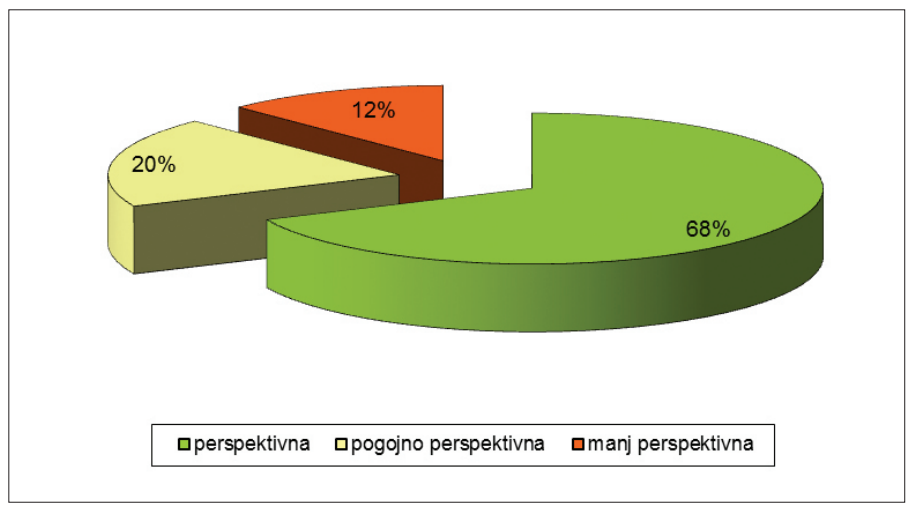

Vir/Source: Anketiranje december 2009 - marec 2010

Ekoloških kmetij, ki jih glede na demografsko sestavo gospodinjstev prištevamo med razvojno manj perspektivne, je v anketiranem vzorcu $12 \%$. Te kmetije se soočajo s postopnim (včasih tudi razmeroma hitrim) ugašanjem, vendar nekateri primeri po Sloveniji kažejo, da obstajajo tudi izjeme. Z vidika pridelave ekološke hrane za povečanje lokalne oskrbe je ta skupina kmetij dolgoročno manj, oziroma (ne)perspektivna. Primerjave s sorodnimi raziskavami demografske slike kmetij v Sloveniji pa kažejo, da je delež demografsko manj perspektivnih ekoloških kmetij nižji kot pri konvencionalnih kmetijah v različnih regijah (Lampič, 2008; 2011).

Dobro petino kmetij s starejšo in srednjo generacijo smo uvrstili med pogojno perspektivne. V primeru, da si srednja generacija ne bo uspela najti partnerjev in ustvariti družine, so te kmetije srednjeročno manj perspektivne. Ko starejša generacija ne bo več zmožna delati na kmetiji, bo za delo ostal samo član srednje generacije (star 40 ali 50 let), ki pa ne bo zmogel upravljati in razvijati dejavnosti v obstoječem obsegu. Prav pri ekoloških kmetovalcih pa imamo številne primere, ko se posamezniki v srednjih letih odločijo za drugačen način življenja, oziroma nov način kmetovanja.

Gospodarsko močna in optimistična bi morala biti predvsem trigeneracijska gospodinjstva, tista s srednjo in mlado generacijo ter mlada gospodinjstva. Pri anketiranju smo zabeležili 68 \% tovrstnih ekoloških kmetij, kar je glede na siceršnje razmere v Sloveniji bistveno ugodnejše in odstopa od vseh dosedanjih raziskav demografske vitalnosti slovenskih kmetij (Lampič, 2008; 2011; Klemenčič in sod., 2008). Posebej velja izpostaviti 45 \%-ni delež kmetij s srednjo in mlado generacijo, za katere pričakujemo, da bodo tudi v prihodnje nosilke razvoja in inovativnosti tako pridelave kot predelave in tudi ponudbe ekoživil. 


\subsection{Tržni potencial}

Ključni element $\mathrm{z}$ vidika izboljšanja lokalne oskrbe $\mathrm{s}$ hrano je trženje pridelkov in predelanih živil. V celotnem vzorcu anketiranih ekoloških pridelovalcev jih je kar 92 \% že vpetih v različne prodajne poti.

Slika 4: Deleži prodaje pridelkov na anketiranih kmetijah

Figure 4: Share of crop sales in the surveyed farms

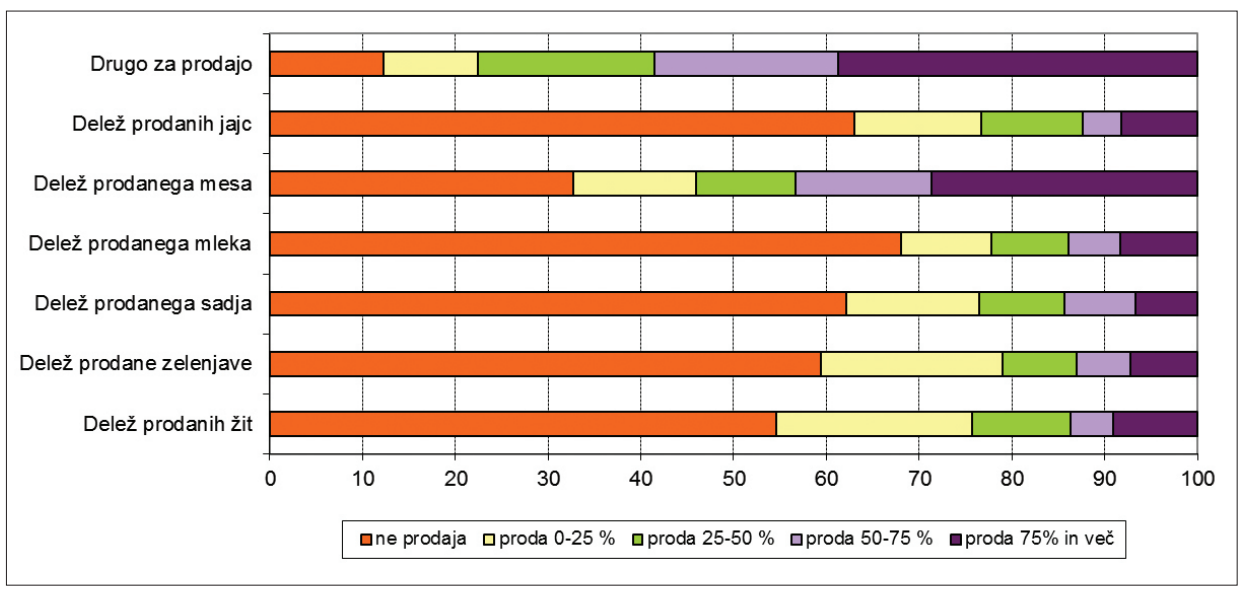

Opomba: Prikazane so kmetije, ki določeno skupino pridelkov tudi dejansko pridelujejo. Vir/Source: Anketiranje december 2009 - marec 2010

$\mathrm{Z}$ vidika lokalne oskrbe so zanimive predvsem prodajne poti posameznih pridelkov ekoloških kmetij. Največ kmetov prodaja meso (skoraj 70 \%), žita (45 \%) in zelenjavo (40 \%). Prodajno izrazito zanimiva je skupina t.i. drugih pridelkov (zelišča, oljčno olje, različni namazi, ipd.), katere prodaja skoraj 90 \% kmetov. Vendar pa takšna struktura prodaje ne odraža celotnega tržnega potenciala posameznih skupin ekoživil. Zgovoren primer je meso, katerega večina vprašanih kmetov le redko prodaja kot ekološko živilo. Ugotovili smo, da tiste anketirane kmetije, ki pridelujejo za trg, največji del pridelkov prodajo neposredno na kmetiji (70\%) in na ekološki tržnici $(18 \%)$. V letu 2010 je v Sloveniji delovalo 13 ekoloških tržnic, na katerih prodaja od 110 do 120 ekoloških kmetov (Slabe in sod., 2010). 
Slika 5: Glavne prodajne poti za posamezne pridelke z ekoloških kmetij

Figure 5: The main sales channels for individual products from organic farms

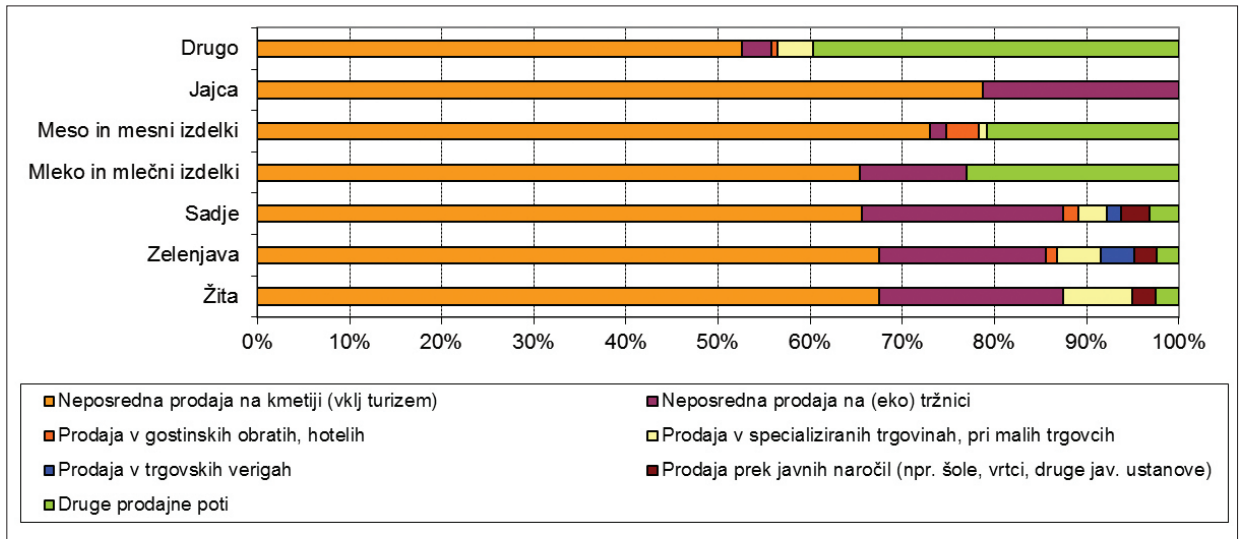

Vir/Source: Anketiranje december 2009 - marec 2010

Iz slike 5 je razvidno, da kmetje veliko večino žit in žitnih izdelkov, zelenjave in sadja prodajo neposredno na kmetiji, za približno četrtino je zelo pomembna tudi (eko)tržnica.

Le slaba tretjina rejcev molznic prodaja mleko in mlečne izdelke, od tega veliko večino na kmetiji, le redki na tržnici. Meso in mesne izdelke prodajata dve tretjini rejcev, spet pretežni del na kmetiji. Jajca prodaja dobra tretjina rejcev nesnic, skoraj vsi večji del prodajo na kmetiji, četrtina pa večino jajc proda na tržnici. Anketirane kmetije le v manjši meri uporabljajo preostale tržne poti.

Trgovci izpostavljajo pomen zadostne, pestre in stalne dobave ekoživil, kar za slovenske pridelovalce (v povprečju majhni) pomeni nujnost povezovanja in skupnega nastopanja na tržišču. Zato nas je v raziskavi zanimala tudi stopnja obstoječega sodelovanja med kmeti. Pri tem smo izhajali iz predpostavke, da lahko intenzivnejše povezovanje med kmeti pozitivno vpliva na obseg in pestrost lokalne oskrbe. Izkazalo se je, da sta obseg in vrsta povezovanja med kmeti skromna. Rezultati ankete kažejo, da se individualno sodelovanje med kmeti statistično razlikuje glede na tip pridelave (pozitivno odstopajo pridelovalci zelenjave) in glede na vključenost v Zvezo Biodar.

Oglašuje približno tretjina vseh anketiranih pridelovalcev, kar dobra polovica pa navaja pomen pridobljenega zaupanja pri kupcih ('dober glas'). Petina oglašuje na spletu, desetina na letakih, v časopisih in na televiziji. Lastno spletno stran ima $5 \%$ anketiranih pridelovalcev.

Tržno naravnane kmetije praviloma pridobijo večji del dohodka v gospodinjstvu iz kmetijske dejavnosti. Ob vseh pridržkih glede nezanesljivosti tovrstnih pavšalnih ocen smo anketirane kmete zaprosili za oceno, kolikšen delež dohodka njihovih gospodinjstev izvira iz kmetijske dejavnosti (vključno s kmetijskimi subvencijami). Tudi med ekološkimi pridelovalci prevladujejo majhne dopolnilne kmetije, katerim dohodek iz kmetovanja pomeni le dopolnitev k družinskemu proračunu. Kar 56 \% anketiranim kmetijam (142) dohodek iz kmetijstva (vključno s proračunskimi izplačili) prinaša do $25 \%$ vseh dohodkov gospodinjstva. 
Kmetij, katerim dohodek iz kmetijstva prinaša med 25 in $50 \%$ vseh dohodkov, je bilo v anketiranem vzorcu $26 \%$ (67 kmetij), 17 kmetijam (7 \%) dohodek iz kmetijstva prinaša 50 do $75 \%$, samo 30 kmetijam (12 \%) pa dohodek iz kmetijstva prinaša nad $75 \%$ vseh dohodkov.

Slika 6: Delež dohodka anketiranih gospodinjstev, ki izhaja iz kmetijske dejavnosti

Figure 6: Proportion of surveyed households income derived from agricultural activities

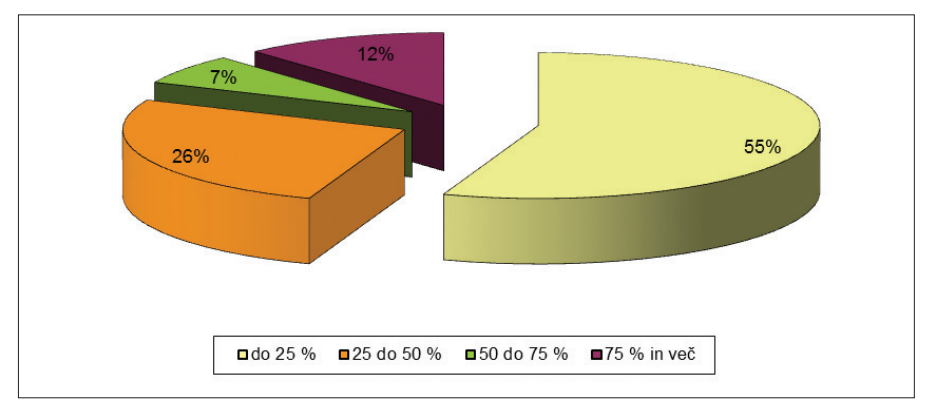

Vir/Source: Anketiranje december 2009 - marec 2010

Odločilnega pomena za bodoči razvoj ekološkega kmetijstva je zaznavanje/ocena prihodnosti kmetije s strani samih kmetov - gospodarjev. Polovica, oziroma 129 vprašanih, je povedala, da bo kmetija ostala v okviru sedanjega obsega in ohranila dejavnosti. Dobra tretjina (91 pridelovalcev) je ocenila, da se kmetiji odpirajo nove možnosti, 14 \% (36 pridelovalcev) pa je bilo mnenja, da kmetija nima prave prihodnosti.

Slika 7: Dohodek od kmetijstva in načrti, povezani s kmetovanjem na anketiranih ekoloških kmetijah Figure 7: Income from agriculture and future plans related to agriculture in the surveyed organic farms

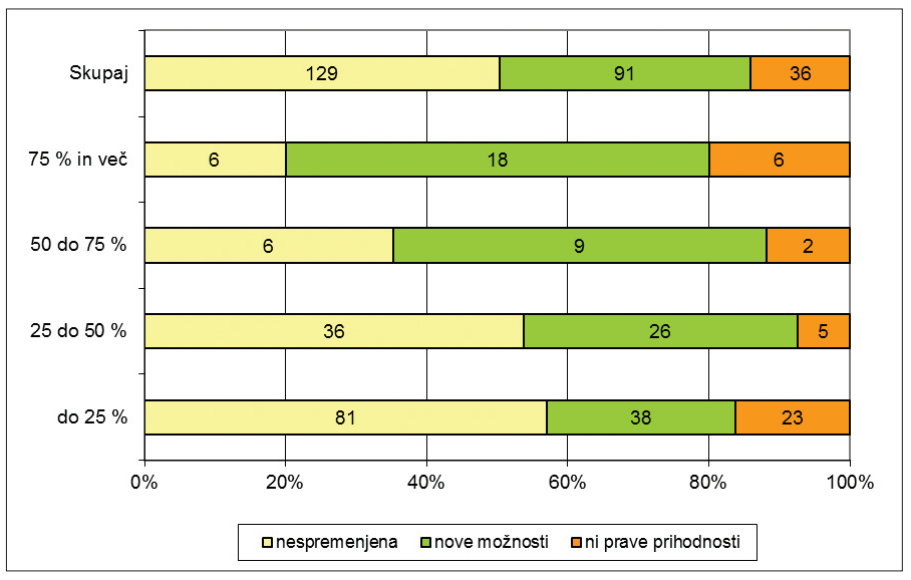

Vir/Source: Anketiranje december 2009 - marec 2010 
Ekološke kmetije vidijo nove priložnosti v razvoju dopolnilnih dejavnosti na kmetiji (predvsem na področju turizma), kar se v kombinaciji z ekološko pridelavo zdi zelo smiselno. Druga najpogosteje izbrana možnost je vlaganje v nove stroje in opremo, kar načrtuje dobrih $13 \%$ vprašanih. Na priložnosti, ki jih prinaša povpraševanje po ekoživilih, opozarja pomemben delež (12 \%) anketirancev, ki načrtujejo povečanje obsega prodaje.

\section{OVIRE PRI POVEČANJU TRŽENJA NA KMETIJI IN NAČRTOVANE SPREMEMBE}

Z vidika povečanja lokalne oskrbe so pomembne tako ovire, ki jih pridelovalci doživljajo pri trženju, kot tudi ovire pri samem kmetovanju. V obeh primerih so anketiranci lahko izbrali in rangirali do tri odgovore.

Anketiranci so najpogosteje ( $\mathrm{v}$ več kot polovici primerov) navedli 'obremenitev $\mathrm{z}$ administracijo, birokracijo', ki jo skoraj dve tretjini od njih označuje tudi kot največjo oviro (slika 8).

Slika 8: Najpomembnejše ovire pri ekološkem kmetovanju na anketiranih kmetijah Figure 8: The main barriers to organic farming in the surveyed farms

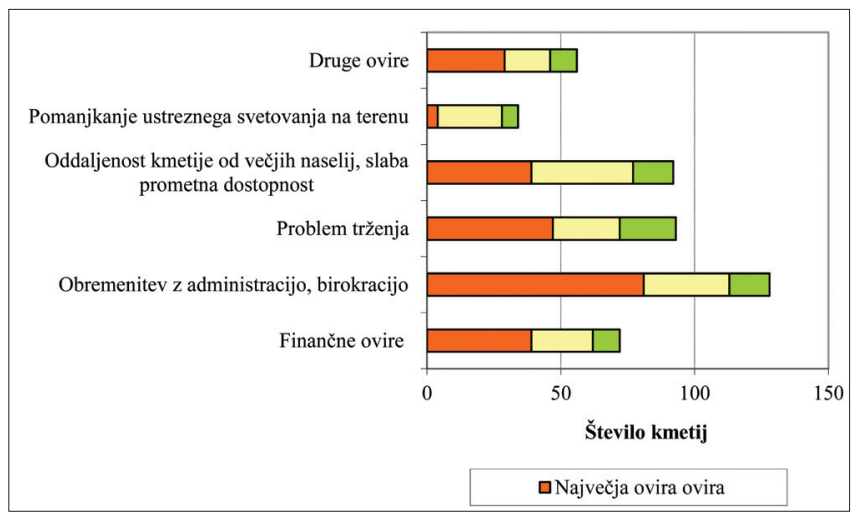

Vir/Source: Anketiranje december 2009 - marec 2010

Sledita 'problem trženja' in 'oddaljenost kmetije od večjih naselij' ter 'slaba prometna dostopnost' (dobra tretjina pridelovalcev). Trženje je najpomembnejša ovira za polovico anketiranih. Oddaljenost kmetije je najpomembnejša ovira za skoraj 42 \% kmetij s tem izbranim odgovorom. Finančne ovire je omenilo 28,1 \%, 'druge ovire' četrtina, pomanjkanje svetovanja je izbralo dobrih $13 \%$ vprašanih. V kategoriji 'drugo' so vprašani navajali zelo različne vrste ovir (pomanjkanje delovne sile in več ročnega dela, naravni dejavniki, razdrobljenost kmetijskih zemljišč, idr.).

Pri ugotavljanju glavnih ovir za trženje (slika 9) so anketiranci lahko izbirali med sedmimi možnostmi in jih rangirali. 
Slika 9: Najpomembnejše ovire pri trženju na anketiranih ekoloških kmetijah Figure 9: The main obstacles to the marketing in the surveyed organic farms

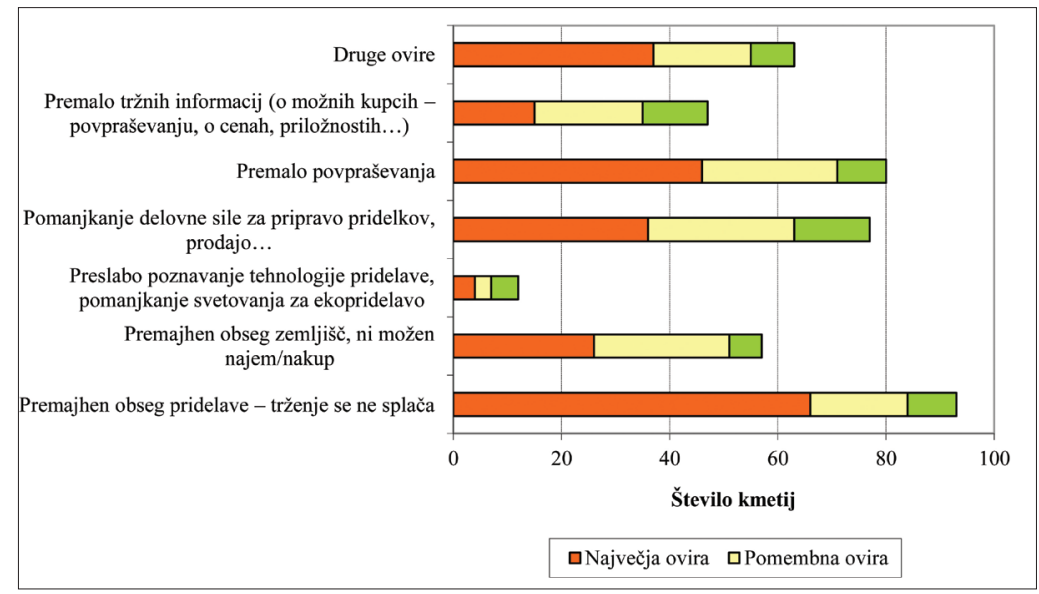

Vir/Source: Anketiranje december 2009 - marec 2010

Več kot tretjina vprašanih je kot oviro za povečanje trženja izbrala premajhen obseg pridelave, kar je bila za skoraj tri četrtine tudi glavna ovira. Sledi premalo povpraševanja, kar je bila prva izbira za dobro polovico od 80 (tretjina) vprašanih, ki so navedli to oviro. Sledi pomanjkanje delovne sile, ki jo je navedla slaba tretjina vprašanih (kot glavno jo je izbrala slaba polovica le-teh). Premajhen obseg zemljišč in odsotnost možnosti za najem ali nakup je navedla dobra petina vprašanih (to oviro je kot glavno navedla slaba polovica le-teh).

Zanimivo je, da je malo vprašanih (slabih $5 \%$ ) kot oviro navedlo preslabo poznavanje tehnologije pridelave in pomanjkanje svetovanja za ekopridelavo. Ocenjujemo, da razlog ni v na splošno zelo dobrem svetovanju za ekopridelavo in znanju pridelovalcev, temveč predvsem v tem, da pridelovalci druge ovire bolj opazijo in občutijo.

\section{SKLEP - MOŽNOSTI ZA IZBOLJŠANJE TRAJNOSTNE LOKALNE OSKRBE S HRANO}

Zagotavljanje prehranske varnosti s stabilno pridelavo varne, kakovostne in potrošniku dostopne hrane je v Resoluciji o strateških usmeritvah razvoja kmetijstva (2011) prepoznano kot osnovni strateški cilji razvoja kmetijstva in proizvodnje hrane.

Naša ocena potencialov za ekološko pridelavo v Sloveniji izhaja iz analize trenutnega obsega in strukture pridelave, raziskave stopnje tržne naravnanosti ekoloških pridelovalcev, analize demografskega potenciala in dejanskih načrtov za prihodnost, kot jih imajo kmetje ekološki pridelovalci. Obseg razpoložljivih informacij pa ni bil zadosten tudi za količinsko oceno potenciala lokalne ponudbe ekološko pridelane hrane v Sloveniji. V preglednici 5 povzemamo ključne ugotovitve raziskave in jih v nadaljevanju kratko komentiramo. 
Preglednica 5: Prikaz ocene potencialov za ekološko pridelavo za lokalno oskrbo s hrano v Sloveniji

Table 5: Estimates of the potential of organic food production for local food supply in Slovenia

\begin{tabular}{|c|c|c|}
\hline $\begin{array}{l}\text { Element } \\
\text { ocene }\end{array}$ & $\begin{array}{l}\text { Ocena } \\
\text { potenciala }\end{array}$ & Opis in razlaga ocene \\
\hline $\begin{array}{l}\text { Obseg in } \\
\text { struktura } \\
\text { pridelave }\end{array}$ & slabo & $\begin{array}{l}\text { - Neenakomerna prostorska razporeditev ekoloških kmetij v } \\
\text { - Sloveniji. } \\
\text { Upočasnjena rast števila ekoloških kmetij in obsega ekoloških } \\
\text { zemljišč po letu } 2008 \text {. } \\
\text { - Izrazito neugodna struktura ekoloških kmetijskih zemljišč s } \\
\text { prevladujočim deležem travinja ( } 90 \text { \%). } \\
\text { - Pretežen delež ekoloških kmetij v Sloveniji je na območjih z } \\
\text { OMD, zato posledično prevladujejo živinorejske ekološke kmetije. } \\
\text { - Nerazvito trženje ekoživil živalskega izvora. }\end{array}$ \\
\hline $\begin{array}{l}\text { Tržna } \\
\text { naravnanost } \\
\text { ekoloških } \\
\text { pridelovalcev }\end{array}$ & dobro & $\begin{array}{l}\text { - Visok delež tržno usmerjenih ekoloških kmetij ( } 92 \% \text { anketiranih). } \\
\text { - } 26 \% \text { anketiranih kmetov bo v prihodnje povečalo obseg trženja } \\
\text { ali uvedlo nove tržne poti. }\end{array}$ \\
\hline $\begin{array}{l}\text { Demografski } \\
\text { potencial }\end{array}$ & dobro & $\begin{array}{l}\text { - Demografsko vitalnih in delovno perspektivnih je kar } 69 \text { \% } \\
\text { anketiranih ekoloških kmetij. } \\
\text { Prevladujejo trigeneracijska kmečka gospodinjstva, kar je ugodno } \\
\text { z vidika obsega in prilagodljivosti razpoložljivega dela, znanja in } \\
\text { ambicij za razvoj kmetije. }\end{array}$ \\
\hline $\begin{array}{l}\text { Načrti } \\
\text { ekoloških } \\
\text { kmetov }\end{array}$ & zmerno & $\begin{array}{l}\text { - } \quad \text { Nove možnosti za razvoj kmetije vidi } 35 \text { \% ekoloških kmetov. } \\
\text { Ekološke kmetije, katerih dohodek izvira pretežno iz kmetijske } \\
\text { dejavnosti (preko } 50 \text { \%), so bolj usmerjene v razvoj, uvajanje } \\
\text { novosti in povečanje obsega pridelave. } \\
\text { Povezovanje z namenom sodelovanja pri trženju je zelo slabo } \\
\text { razvito. Manjši del kmetov tu sicer načrtuje izboljšave. }\end{array}$ \\
\hline
\end{tabular}

Poenostavljen shematičen prikaz ocene potencialov ekološke pridelave za lokalno oskrbo s hrano nakazuje nekatere dobre razvojne možnosti in povečanje vloge ekološke pridelave pri izboljšanju lokalne/regionalne oskrbe s hrano. Kljub razmeroma neugodni strukturi ekološko obdelanih kmetijskih zemljišč, usmeritvi pridelovalcev (prevladuje živinoreja) ter upočasnjeni rasti števila ekoloških kmetij in ekološko obdelanih zemljišč, pa tržna naravnanost obstoječih kmetij skupaj z razmeroma ugodno demografsko sliko pomeni dobre obete za prihodnji razvoj. Tudi inovativnost in nove razvojne ideje obstoječih ekoloških kmetij kažejo na velik razvojni potencial, a je zelo pomembna tudi finančna podpora državnih idr. ustanov, delovanje medijev, idr. Enako velja za sodelovanje kmetij z namenom bolj učinkovitega trženja.

Ekološko pridelavo in ponudbo v Sloveniji označuje predvsem nezadostna izkoriščenost možnosti prodaje ekoloških pridelkov. Obstoječa slovenska ekološka pridelava je že usmerjena večinoma v lokalno oskrbo, odgovori anketiranih kmetij o načrtih glede trženja pa kažejo, da bo tako ostalo tudi v prihodnje. Vendar je z vidika dolgoročnega razvoja trajnostne lokalne oskrbe s kakovostnimi ekološkimi živili slovenskega porekla odločilno 
predvsem dvoje: ustrezna količina pridelkov na lokalnem trgu in zainteresiranost ter ozaveščenost lokalnih kupcev.

Raziskava med slovenskimi ekološkimi pridelovalci je pokazala predvsem naslednje:

- z vidika povečanja oskrbe s slovenskimi ekološkimi živili je ključno preusmerjanje večjih pridelovalcev (zlasti zelenjave in sadja) v ekološko pridelavo;

- obstajajo še veliki potenciali za povečanje neposredne prodaje na kmetijah in na (eko)tržnicah, $\mathrm{v}$ specializiranih trgovinah, $\mathrm{v}$ trgovskih verigah in $\mathrm{v}$ okviru javnih naročil (Akcijski načrt za zeleno javno naročanje ..., 2009). Potrošniki praviloma dajejo prednost domačim ekoživilom, boljši kakovosti in svežosti pridelkov ter ugodnejšim cenam pri neposrednem nakupu (npr. v primerjavi z uvoženimi svežimi pridelki v trgovskih verigah);

- uresničevanje potenciala je odvisno od ovir, ki jih pridelovalci čutijo: pomemben del pridelovalcev se za trženje ne odloča zaradi različnih razlogov (npr. prenizkega povpraševanja, premajhnega obsega pridelave, kar kaže predvsem na težave pridelovalcev pri medsebojnem povezovanju in v povezavah s trgom);

- promoviranje ekoloških pridelkov na kmetijah prek 'dobrega glasu' že samo po sebi odraža pretežno lokalno usmerjenost ponudnikov ekoloških živil. Na ta način se krepi zaupanje med pridelovalcem in potrošnikom ter se vzpostavlja dolgoročno sodelovanje;

- $\mathrm{k}$ uresničitvi potenciala bi pomembno prispevale izboljšave pri prenosu znanja na vseh področjih, od pridelave do trženja.

\section{Viri in literatura}

Akcijski načrt razvoja ekološkega kmetijstva v Sloveniji do leta 2015. 2005. URL: http:// www.mkgp.gov.si/fileadmin/mkgp.gov.si/pageuploads/ssk/Akcijski_nacrt-ANEK. pdf (Citirano 4. 5. 2011).

Akcijski načrt za zeleno javno naročanje za obdobje 2009-2012. 2009. URL: http://www. svrez.gov.si/fileadmin/svez.gov.si/pageuploads/docs/javna_narocila/27_sv_-_zeleno_JN.pdf (Citirano 23. 9. 2011).

An analysis of the EU organic sector. 2010. European Commission, Directorate-General for Agriculture ad Rural Development. 2010. URL: http://ec.europa.eu/agriculture/ analysis/markets/organic_2010_en.pdf (Citirano 4. 8. 2010).

Klemenčič, M. M., Lampič, B., Potočnik Slavič, I. 2008. Življenjska (ne)moč obrobnih podeželskih območij v Sloveniji (GeograFF 3). Ljubljana, Filozofska fakulteta, Oddelek za geografijo, 149 str.

Kuhar, A., Juvančič, L., 2010. Determinants of purchasing behaviour for organic and integrated fruits and vegetables in Slovenia. Agricultural economics review, 11, 2, str. 70-83. Thessaloniki.

Lampič, B., 2005. Kmetijstvo kot priložnost sonaravnega razvoja podeželja v Sloveniji. Dela, 23, str. 167-219. Ljubljana.

Lampič, B., 2008. Agrarno obremenjevanje okolja na Slovenskem v energetski osvetlitvi (na izbranih primerih). Doktorsko delo. Ljubljana, Filozofska fakulteta, Oddelek za geografijo, 208 str. 
Lampič, B., 2011. Sedanjost in prihodnost kmetijstva. V: Spodnje Podravje pred izzivi trajnostnega razvoja (GeograFF 9). Ljubljana, Filozofska fakulteta, Oddelek za geografijo, str. 101-135.

Marktbericht. Europäer lassen sich Bio für rund 18 Mrd. EUR schmecken. Biofach, 2011. URL: http://www.biofach.de/de/presse/presseinformationen/marktbericht_europa (Citirano 28. 10. 2011).

MKGP, 2008. Register ekoloških pridelovalcev - zbirka podatkov ekoloških kmetij, vključenih v nadzor ekološke pridelave. Ministrstvo za kmetijstvo, gozdarstvo in prehrano, 2008.

MKGP 2011: Analiza stanja ekološkega kmetijstva v Sloveniji. Ministrstvo za kmetijstvo, gozdarstvo in prehrano. 2011. URL: http://www.mkgp.gov.si/si/o_ministrstvu/ direktorati/direktorat_za_kmetijstvo/starasektor_za_sonaravno_kmetijstvo/oddelek za_kmetijstvo_in_okolje/kmetijsko_okoljska_placila/ekolosko_kmetovanje/ekolosko_kmetijstvo_dejstva_in_podatki/7_analiza_stanja_ekoloskega_kmetijstva_v_sloveniji (Citirano 27. 10. 2011)

Potočnik Slavič, I., 2010. Endogeni razvojni potenciali slovenskega podeželja (GeograFF 7). Ljubljana, Filozofska fakulteta, Oddelek za geografijo, 131 str.

Resolucija o strateških usmeritvah razvoja slovenskega kmetijstva in živilstva do leta 2020 - »Zagotovimo.si hrano za jutri«). Uradni list RS, 25 (4. 4. 2011), Ljubljana.

Slabe, A., Kuhar, A., Juvančič, L., Tratar Supan, A. L., Lampič, B., Pohar, J., Gorečan, M., Kodelja, U., 2010. Analiza stanja in potencialov za rast ponudbe ekoloških proizvodov v luči doseganja ciljev Akcijskega načrta za razvoj ekološkega kmetijstva v Sloveniji do 2015. Zaključno poročilo. Biotehniška fakulteta, Oddelek za zootehniko in Inštitut za trajnostni razvoj, 78 str.

SURS 2011. Bilance proizvodnje in porabe za koledarsko leto. Statistični urad Republike Slovenije. URL: http://pxweb.stat.si/pxweb/Database/Okolje/15_kmetijstvo_ribistvo/12_prehranske_bilance/02_15635_koled_bilance/02_15635_koled_bilance.asp (Citirano 27. 10. 2011).

Terenska raziskava - anketiranje potrošnikov. Oddelek za geografijo, Filozofska fakulteta. 2010.

The organic market in Europe. Overview and market access information. 2011. URL: http:/www.sippo.ch/internet/osec/en/home/import/publications/food.-ContentSlot-98296-ItemList-61735-File.File.pdf/SIPPO_Manual_18.04.2011_final.pdf (Citirano 27. 10. 2011).

Uredba o zelenem javnem naročanju (predlog). 2010. Ministrstvo za finance. URL: http:// www.mf.gov.si/si/delovna_podrocja/sistem_javnega_narocanja/predlogi_predpisov (Citirano 27. 10. 2011). 